\title{
PELATIHAN STARUP DIGITAL DAN DIGITAL MARKETING BAGI SISWA-SISWI SEKOLAH MENENGAH ATAS (SMA) NEGERI 1 METRO
}

\author{
${ }^{1}$ Yan Aditiya, ${ }^{2}$ Sri Rahayu, ${ }^{3}$ Stefanus Rumangkit \\ 1,2,3Institut Informatika dan Bisnis Darmajaya, Bandar Lampung, Indonesia \\ Email: aditiya@darmajaya.ac.id
}

(Diterima: 7 September 2021; Direvisi: 24 September, 2021; Dipublikasikan: November 2021)

\begin{abstract}
Abstrak
Kegiatan PKM ini dilaksanakan di SMAN 1 Metro yang erfokus pada kelas XII karena belum adanya minat dari siswa dan siswi SMAN 1 Metro untuk bewirausaha dan masih belum memahami bagaimana caranya memulai bisnis. Berdasarkan wawancara yang dilakukan dengan beberapa siswa, ditemukan fakta bahwa: 1) Siswa - Siswi belum memiliki minat untuk berwirausaha, 2) terdapat siswa yang memiliki minat untuk memulai berwirausaha, tetapi masih belum memiliki pengetahuan yang cukup, 3) minimnya pengetahuan siswa-siswi mengenai digital marketing. Hal ini juga diperkuat dengan hasil survei yang menunjukkan bahwa dari 30 siswa yang diajukan pertanyaan terkait minat berwirausaha hanya 5 yang menjawab berminat untuk berwirausaha, Lalu tim PKM juga menanyakan tentang digital marketing, dari 30 siswa yang menjawab, hanya 10 siswa yang mengetahui digital marketing, walaupun jawaban yang dilontarkan hanya sebatas pengetahuan dasar.Oleh karena itu, tim pengabdi melihat bahwa ini merupakan salah satu tantangan bagi tim pengabdi untuk membantu SMAN 1 Metro untuk berbagi pengetahuan mengenai memulai bisnis dan digital marketing. Metode yang digunakan yaitu sosialisasi/ penyuluhan, diskusi, simulasi, dan penerapan. Hasil kegiatan PKM ini yaitu pemaparan materi E-Business Concept, Social Media Marketing, Management Branding Media Social, Personal Branding, pendampingan bisnis dan proposal kompetisi nasional FIKSI. Kegiatan PKM ini membawa dampak yang positif yang menjadi rinspirasi untuk menjadi wiraswasta muda, dan memiliki pengetahuan dasar untuk menjalankan bisnis. Pengetahuan yang dimiliki oleh siswa dan siswi akan mendorong minta berwiraswasta mereka. Materi yang dipaparkan membuat para siswa mengetahui bagaimana cara simpel untuk memulai bisnis, membangun merek dengan pemanfaatan media sosial, dan membangun personality sebagai pebisnis.
\end{abstract}

Kata Kunci: Digital Marketing, Sosial Media Marketing, Branding, SMAN 1 Metro

\begin{abstract}
:
The Community Service Team (PKM) will carry out PKM activities at SMA Negeri 1 Metro (SMAN 1 Metro), and focus on class XII students, totaling 388 students. This PKM activity was carried out at SMAN 1 Metro because there was no interest from SMAN 1 Metro students for entrepreneurship and still did not understand how to start a business. Based on interviews conducted with several students, it was found that: 1) Students do not have an interest in entrepreneurship, 2) there are students who have an interest in starting entrepreneurship, but still do not have sufficient knowledge, 3) students' lack of knowledge about digital marketing. Therefore, the service team saw that this was one of the challenges for the service team to help SMAN 1 Metro to share knowledge about starting a business and digital marketing. The method used in this PKM activity is the method of socialization / counseling, discussion, simulation, and application. The results of the PKM activities that have been carried out are the presentation of material on E-Business Concept, Social Media Marketing, Management Branding Social Media, Personal Branding, business assistance and proposals for the FIKSI national competition. This PKM activity has a positive impact on students of SMAN 1 Metro, they become inspired to become young entrepreneurs, and have basic knowledge to run a business. The knowledge possessed by students and students will encourage them to ask for entrepreneurship. The material presented made the students know how simple it is to start a business, build a brand by using social media, and build personality as a businessman.
\end{abstract}

Keywords: Digital Marketing, Sosial Media Marketing, Branding, SMAN 1 Metro 


\section{PENDAHULUAN}

Indonesia merupakan salah satu negara yang memiliki jumlah penduduk terbesar di dunia. Salah satu masalah yang dihadapi oleh Indonesia adalah tingkat pengangguran yang tinggi. Data Badan Pusat Statistik (BPS) Indonesia mencatat bahwa Februari 2021 terdapat 8,75 juta jiwa masyarakat Indonesia yang merupakan angkatan kerja masuk dalam kategori pengangguran. Oleh karena itu, pemerintah sedang berupaya untuk mencari suatu solusi untuk mengatasi permasalah tersebut. Salah satu cara pemerintah, untuk mengatasi pengangguran di Indonesia dengan menggiatkan program ekonomi kreatif.

Melalui ekonomi kreatif diharapkan dapat muncul entrepreneur muda yang dapat menciptakan suatu produk yang inovatif yang dapat menjadi sumber penghasilan bagi mereka. Sehingga akan berdampak pada pertumbuhan ekonomi Indonesia. Melalui ekonomi kreatif, Indonesia mengalami peningkatan PDB setiap tahunnya. Pada tahun 2014, Ekonomi kreatif menyumbangkan PDB Indonesia sebesar Rp. 784,82 Triliun, sedangkan pada triwulan II tahun 2021, PDB Indonesia naik sebesar Rp4.175,8 triliun (BPS, 2021). Fakta ini menunjukkan bahwa ekonomi kreatif melalui entrepreneur muda memberikan kontribusi terhadap peningkatan perekonomian nasional.

Digital marketing merupakan strategi penjualan online dimana penjualan online adalah suatu aktifitas jual beli yang dilakukan secara online, dalam hal ini pembeli dan penjual tidak melakukan transaksi langsung secara tatap muka yang entu media yang digunakan dapat berupa websitemaupun aplikasi yang di akses melalui perangkat elektronik (Haryadi et al., 2021). Sedangkan menurut (Pradiani, 2017) Digital Marketing adalah salah satu media pemasaran yang saat ini sedang banyak diminati oleh masyarakat untuk medukung berbagai kegiatan yang dilakukan

Atas fakta diatas, untuk meningkatkan jumlah entrepreneur di usia muda merupakan suatu tantangan yang dihadapi. Oleh karena itu, salah satu cara menghadapi tantangan tersebut adalah dengan mendidik siswa-siswi SMA untuk menjadi entrepreneur sejak usia muda.

Tim Pengbdian Kepada Masyarakat (PKM) akan melaksanakan kegiatan PKM di SMA Negeri 1 Metro (SMAN 1 Metro), dan berfokus pada siswa-siswi kelas XII yang berjumlah 388 siswa. Kegiatan PKM ini dilaksanakan di SMAN 1 Metro karena belum adanya minat dari siswa dan siswi SMAN 1 Metro untuk bewirausaha dan masih belum memahami bagaimana caranya memulai bisnis. Berdasarkan wawancara yang dilakukan dengan beberapa siswa, ditemukan fakta bahwa: 1) Siswa - Siswi belum memiliki minat untuk berwirausaha, 2) terdapat siswa yang memiliki minat untuk memulai berwirausaha, tetapi masih belum memiliki pengetahuan yang cukup, 3) minimnya pengetahuan siswa-siswi mengenai digital marketing.

Hal ini juga diperkuat dengan hasil survei yang menunjukkan bahwa dari 30 siswa yang diajukan pertanyaan terkait minat berwirausaha hanya 5 yang menjawab berminat untuk berwirausaha, Lalu tim PKM juga menanyakan tentang digital marketing, dari 30 siswa yang menjawab, hanya 10 siswa yang mengetahui digital marketing, walaupun jawaban yang dilontarkan hanya sebatas pengetahuan dasar.

Oleh karena itu, tim pengabdi melihat bahwa ini merupakan salah satu tantangan bagi 
tim pengabdi untuk membantu SMAN 1 Metro untuk berbagi pengetahuan mengenai memulai bisnis dan digital marketing. Selain itu, tim pengabdi juga akan memberikan pengetahuan kepada siswa dan siswi berbinis dengan menggunakan media sosial, yaitu: e-mail marketing, viral marketing, content marketing, dan search engine marketing. Oleh karena itu, Tujuan dilaksanakan kegiatan ini adalah untuk meningkatkan minat siswa dan siswi SMA Negeri 1 Metro untuk berwirausaha. Tim PKM dan SMAN 1 Metro akan bermitra, dimana Tim PKM dengan keahlian yang dimiliki akan membantu SMAN 1 Metro tersebut dalam menyelesaikan masalahmasalah yang dihadapi.

\section{METODE}

Metode yang digunakan dalam kegiatan PKM ini yaitu dengan metode sosialisasi/ penyuluhan, diskusi, simulasi, dan penerapan. Adapun tahapan pelaksanaan kegiatan PKM sebagai berikut:

a) Penentuan kebutuhan pelatihan, pada tahap ini tim PKM melalukan pre test kepada mitra untuk melihat tingkat pemahaman mitra terkait dengan starup dan digital marketing.

b) Mendesain program pelatihan, pada tahap ini tim PKM melakukan perancangan mengenai teknis pelaksanaan kegiatan PKM tersebut. Sehingga, teknik pelaksanaan dapat secara efektif dan efisien untuk membantu mitra.

c) Evaluasi efektivitas program, pada tahap ini tim PKM melakukan post test kepada mitra untuk mengetahui tingkat pemahaman materi yang sudah dijelaskan oleh tim pengabdi.

d) Pendampingan keberlanjutan, Pada tahap ini tim PKM, akan melakukan pendampingan kepada mitra, walaupun kegiatan PKM ini telah berakhir. Hal ini dilakukan agar untuk mendampingi mitra untuk berwirausaha.

\section{HASIL DAN PEMBAHASAN}

Hasil kegiatan pengabdian pada masyarakat dengan fokus pengabdian pada Siswa SMAN 1 Metro dalam pembentukan Youth Entrepreneur dengan beberapa agenda kegiatan dengan tujuan yang telah di paparkan pada tujuan penelitian dengan hasil sebagai berikut:

a) Pemaparan Materi E-Business Concept

Dalam implementasi program PKM ini, kami menyepakati dengan sekolah akan melakukan program pengabdian yang dilakukan secara daring dikarenakan faktor Pandemi yang belum mereda. Oleh karena itu, pemaparan ini memberikan konsep awal memulai bisnis secara elektronik kepada Siswa SMAN 1 Metro. Adapun pesertanya kami lakukan skema eliminasi. Pemateri pada pemaran ini adalah Yan Aditiya Pratama, S.Pd., M.M. sebagai berikut: 


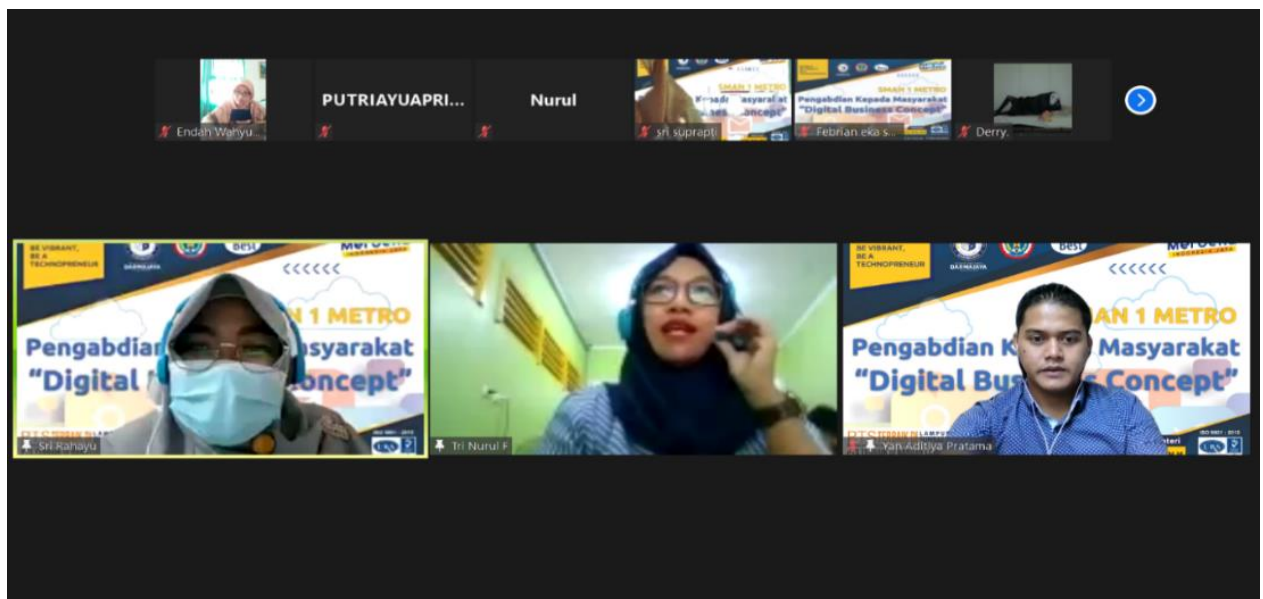

Gambar 1. Pemaparan E-Business Concept

b. Pemaparan Materi Social Media Marketing

Pada sesi selanjutnya, pemateri Yan Aditiya Pratama, S.Pd., M.M. melanjutkan Materi EBusiness Concept secara aplikatif dalam materi Social Media Marketing (SMM). Pertemuan ini dihadiri dengan tujuan untuk lebih mempratikan dan optimalisasi social media dalam peranti pemasaran sebagai berikut:

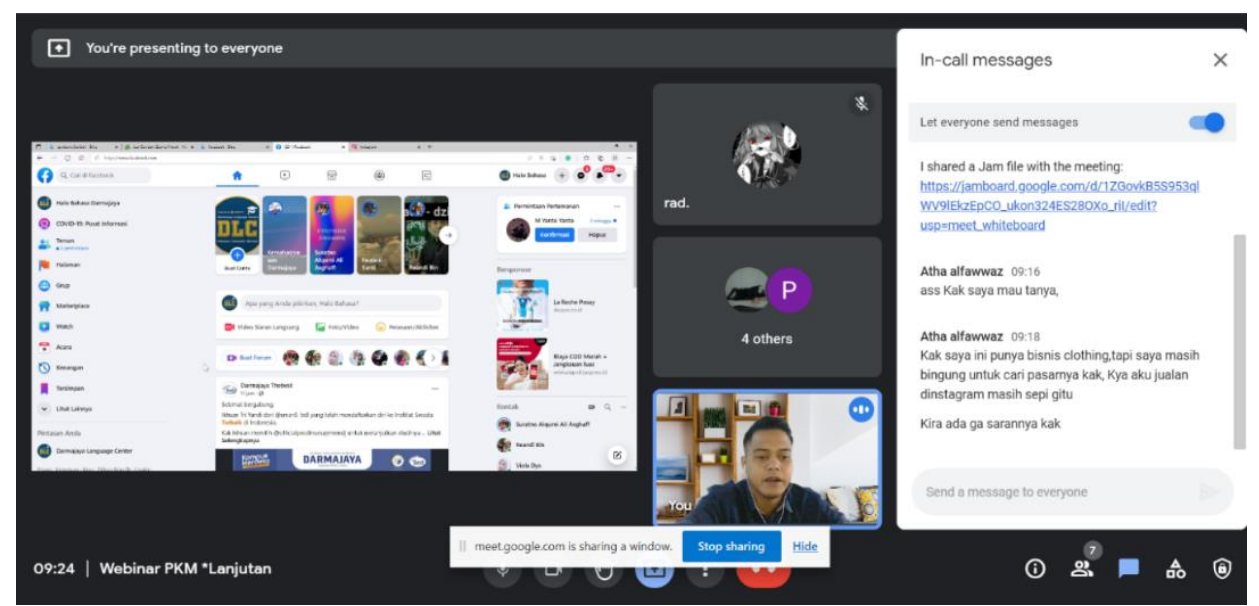

Gambar 2. Pemaparan Social Media Marketing (SMM)

c. Pemaparan Materi Pemanfaatan Media Sosial Untuk branding

Kegiatan ini dilakukan berupa pemaparan materi mengenai manajemen penggunaan platform social media dan menggunakan komentar yang bisa memancing respon audience pada Siswa SMAN 1 Metro yang di fasilitasi dengan pembicara Stefanus Rumangkit, S.E., M.Sc. Berikut dokumentasi kegiatan pedampingan tersebut. 


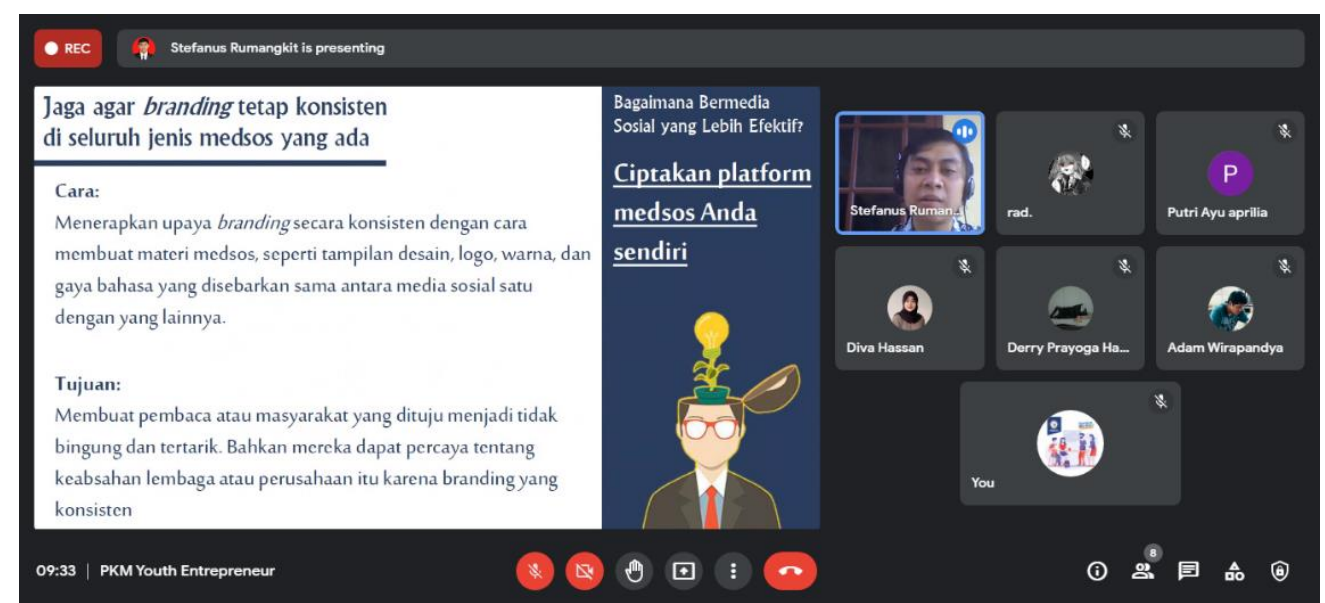

Gambar 3. Pemaparan Social Media branding

d. Pemaparan Materi Personal Branding

Kegiatan lanjutan pada sesi ini diberikan oleh Sri Rahayu, S.E., M.M. tentang Personal Branding. Pemaparan pada sesi ini diharapkan dapat lebih mencitrakan bakal bisnis yang akan dibuat atau bisnis yang sudah dimulai. Berikut dokumentasi kegiatan pedampingan tersebut.

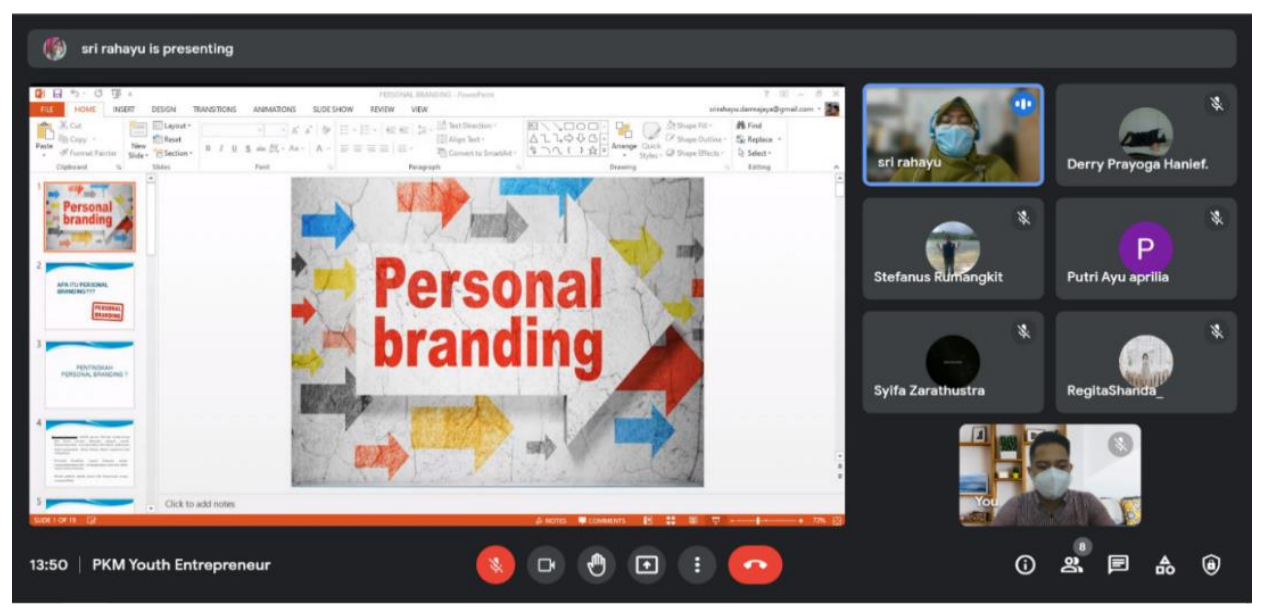

Gambar 4. Pemaparan Personal Branding

Selain itu, kegiatan PKM ini juga mendampingi salah satu siswa SMAN 1 Metro untuk mengikuti Festival Inovasi dan Kewirausahaan Siswa Indonesia (FIKSI) tahun 2021. Tim PKM dan siswa membuat proposal business plan dengan judul "KWU DIGITAL PRINTING". Dan, proposal ini telah disubmit pada kompetisi tersebut. 


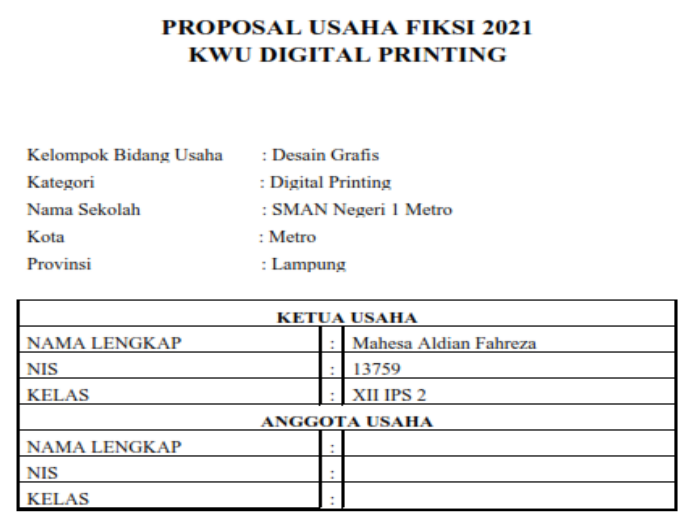

\section{Gambar 5. Pendampingan Proposal Kompetisi Nasional FIKSI Tahun 2021}

Terbentuknya minat dan gerakan dalam berwirausaha di usia muda masih begitu jarang ditemui di era saat ini. Adapun bisnis yang dilakukan adalah bisnis yang bersifat trial error karena tanpa adanya Pendampingan. Perubahan model bisnis dari konvensional ke digital pun menjadi masalah tersendiri di era saat ini. Hal ini ditambah dengan adanya pandemi yang memaksa setiap pelaku bisnis mempelajari konsep bisnis dengan piranti digital dan piranti pendukung lainnya. Pengabdian Kepada Masyarakat (PKM) yang dilakukan oleh tim dosen IIB Darmajaya kepada siswa SMAN 1 Metro diharapkan dapat memberikan gambaran dan petunjuk dalam beradaptasi pada era digital saat ini pada Tema Youth Entrepreneur.

Lebih jauh, kegiatan ini dapat menghasilkan Perbaikan Berkelanjutan pada pola pikir Generasi pada saat ini. Beragam pelatihan yang dilakukan dalam kegiatan Pengabdian Kepada Masyarakat ini antara lain: Pemaparan materi E-Business Concept, Social Media Marketing, Management Branding Media Social, dan Personal Branding. Kegiatan PKM ini membawa dampak yang positif bagi siswa dan siswi SMAN 1 Metro, mereka menjadi terinspirasi untuk menjadi wiraswasta muda, dan memiliki pengetahuan dasar untuk menjalankan bisnis. Pengetahuan yang dimiliki oleh siswa dan siswi akan mendorong minta berwiraswasta mereka. Materi yang dipaparkan membuat para siswa mengetahui bagaimana cara simpel untuk memulai bisnis, membangun merek dengan pemanfaatan media sosial, dan membangun personality sebagai pebisnis.Selain itu, kegiatan PKM ini diimplikasikan dengan dimintanya tim PKM sebagai tim konsultasi pada program FIKSI2021 sebagai wujud terimplementasikannya peran tim ini pada Siswa SMAN 1 Metro.

\section{SIMPULAN}

Munculnya minat berwirausaha pada usia muda merupakan nilai positif yang harus ditanamkan. Dari pengetahuan mitra mengenai digital marketing, diketahui bahwa telah adanya pola yang dapat implementasikan dengan berfokus pada program kompetisi level Sekolah nasional dengan judul "PROPOSAL USAHA FIKSI 2021-KWU DIGITAL PRINTING". Dari kompetisi tersebut diharapkan penggunaan sosial media marketing dapat berjalan dengan akan dimulainya usaha tersebut jika dapat dimenangkan pada kompetisi tersebut. Selain itu, untuk 
mendukung dan meningkatkan pelatihan yang sudah dilakukan, maka pengabdi merekomendasikan sebagai berikut: 1) Harus ada pendampingan berkelanjutan dalam pengelolaan serta pendampingan Youth Entrepreneur di SMAN 1 Metro, 2) Harus ada pelatihan tambahan dan pembangunan Inkubasi Bisnis Sekolah mengenai program-program lain penunjang dalam Youth Entrepreneur di SMAN 1 Metro.

\section{UCAPAN TERIMA KASIH}

Ucapan terima kasih tim pengabdi ucapkan untuk Institut Informatika dan Bisnis Darmajaya yang sudah mendukung pelaksanaan "PELATIHAN STARUP DIGITAL DAN DIGITAL MARKETING BAGI SISWA-SISWI SEKOLAH MENENGAH ATAS (SMA) NEGERI 1 METRO", baik secara administrasi, materi, dan moril. Semoga kegiatan ini dapat menjadi kontribusi nyata bagi Institut Informatika dan Bisnis Darmajaya untuk mengabdi kepada masyarakat.

\section{REFERENSI}

Haryadi, R. N., Rojali, A., \& Fauzan, M. (2021). Sosialisasi Penggunaan Online Shop berbasis Website di UMKM CImanggis. 1(1), 10-16.

Pradiani, T. (2017). Pengaruh sistem pemasaran digital marketing terhadap peningkatan volume penjualan hasil industri rumahan. Jurnal IImiah Bisnis Dan Ekonomi Asia, $11(2), 46-53$.

https://www.bps.go.id/pressrelease/2021/08/05/1813/ekonomi-indonesia-triwulan-ii2021-tumbuh-7-07-persen--y-on-y-.html , diakses pada September 2021

https://databoks.katadata.co.id/datapublish/2021/05/05/jumlah-pengangguran-capai-

875-juta-orang-per-februari-

2021\#: : :text=Badan\%20Pusat\%20Statistik\%20(BPS)\%20mencatat, sebesar\%206 \%2C93\%20juta\%20orang, diakses pada September 2021

Jakarta, Koran (2018). Gerakan Kewirausahaan: Jumlah Wirausaha Tembus 3,1 Persen.

Tersedia di: http://www.koran-jakarta.com/jumlah-wirausaha-tembus-3-1-persen/ , diakses pada November 2018

https://www.gemconsortium.org/report/48772 (Diakses pada tanggal 10 November 2018, pukul $21.00 \mathrm{Wib})$ 